\section{Bacterial superinfection in chickenpox}

Children are probably more susceptible ...

EDIToR,-In their lesson of the week about bacterial complications of childhood chickenpox Andrew J Pollard and colleagues state that there have been no community based studies of complications of chickenpox in Britain. ${ }^{1}$ In a hospital based study we reviewed the clinical data on 222 patients with chickenpox (including 78 children) admitted to our infectious diseases unit from 1989 to $1993 .^{2}$ A third of the children had appreciable secondary bacterial skin infection, and four of these had disease mediated by superantigens (bacterial toxins that bind $\mathrm{T}$ cell receptors at the variable part of the $\beta$ chain away from the conventional antigen binding site, resulting in non-specific stimulation of large numbers of $T$ cells). Only $17 \%$ of the 144 adults had superinfection, and none had superantigen disease. Of five children with eczema, one (who was taking topical steroids) developed secondary skin infection. Six children developed bacteria chest infections, including one with sickle crisis. Of seven asthmatic children, two had pneumonia and one had pneumonitis.

Pollard and colleagues proffer explanations for the increased propensity to invasive streptococcal infection after infection with varicella zoster virus. The lesions of chickenpox predispose to bacterial skin infections, and children are probably more susceptible than adults as they may not have acquired protective antibodies. We suggest that the expression of staphylococcal and streptococcal superantigens is more likely to occur in patients with chickenpox than in those with a simple bacterial infection. Perhaps the microenvironment of vesicles enhances the expression of superantigens, the effect of this being exacerbated by immune impairment mediated by chickenpox.

Pollard and colleagues point out that the association of chickenpox with toxic shock has been largely neglected in standard texts. In our experience it is not an uncommon complication, and it is discussed and illustrated in one of the recent standard texts ${ }^{3}$.

BEGOÑA A BOVILI Registrar

Department of Haematology,

London N19 5NF

BARBARA A BANNISTER Consultant

Department of Infectious and Tropical Diseases,

Royal Free Hospital,

London NW3 $2 \mathrm{PF}$

1 Pollard AJ, Isaacs A, Lyall EGH, Curtis N, Lee K, Walters S, $e t$ al. Potentially lethal bacterial infection associated with varicella zoster virus. $B M \mathcal{F}^{1}$ 1996;313:283-5. (3 August.)

2 Bovill BA, Bannister BA. Review of 26 years' hospital admissions for chicken pox in north London. $\mathcal{F}$ Infect (in press).

3 Bannister BA, Begg NT, Gillespie SH. Infectious disease. Oxford: Blackwell Science, 1996:256-74.

\section{... but it can occur at any age}

EDITOR,-In their lesson of the week Andrew J Pollard and colleagues report 13 cases of severe bacterial infection associated with infection with varicella zoster virus. ${ }^{1}$ While such infection is the commonest cause of morbidity related to chickenpox in otherwise healthy children, it is uncommon in adults. ${ }^{2}$ We report our recent experience of chickenpox complicated by necrotising fasciitis and the toxic shock syndrome in a 32 year old man.

A previously fit white man, who had no underlying immunodeficiency, was admitted to hospital a week after the onset of clinical chickenpox, which he had acquired from his young son.
Initially stable, he rapidly developed high fever and hypotension, with an area of spreading erythema and central skin necrosis on the anterior chest wall. He was transferred to the intensive care unit, where he required haemodynamic and ventilatory support. He was treated with high dose benzylpenicillin, clindamycin, metronidazole, and high dose acyclovir and underwent radical debridement of the chest wall. The necrotic skin was stripped down to the pectoral fascia and appeared healthy. Blood cultures and swabs from the chest wall grew group $A$ streptococci, which were sensitive to penicillin and clindamycin. Electron microscopy yielded negative findings for herpes virus particles, but results of serological tests for varicella zoster virus were consistent with acute primary chickenpox.

Despite aggressive management the patient deteriorated inexorably over the next 36 hours, with generalised erythema, renal failure, worsening lactic acidosis, the adult respiratory distress syndrome, and hypotension unresponsive to maximal inotropic support. He died 72 hours after admission. The features of multiorgan failure in association with isolation of group A streptococci are compatible with the streptococcal toxic shock syndrome. ${ }^{4}$

The fulminating course of sepsis due to group A streptococci seen in this patient has been well described in young children with chickenpox but is rare in adults with the disease (in whom chickenpox pneumonitis is the most important cause of morbidity and death ${ }^{2}$ ). We agree with Pollard and colleagues' conclusions about the potential severity of bacterial superinfection in chickenpox and emphasise that this complication can occur at any age.

AMANDA J BARNES Registrar ALISON S JOHNSON Senior registrar

Microbiology Department,

Manchester Public Health Laboratory,

Withington Hospital, Manchester M20 2LR

MAIRE P SHELLY

Consultant in anaesthesia and intensive care CLIVE I ORTON Consultant plastic surgeon

South Manchester University Hospital NHS Trust,

Wythenshawe Hospital

Manchester M23 9LT

1 Pollard AJ, Isaacs A, Lyall EGH, Curtis N, Lee K, Walter S, et al. Potentially lethal bacterial infection associated with varicella zoster virus. $B M F$ 1996;313:283-5. (3 August.)

2 Arvin A. Varicella-zoster virus. Clin Microbiol Rev 1996;9:36181.

3 Choo PW, Donahue JG, Manson JE, Platt R. The epidemiology of varicella and its complications. $\mathcal{f}$ Infect $D$ is 1995;172:706-12.

4 Wolf JE, Rabinowitz LG. Streptococcal toxic shock-like syndrome. Arch Dermatol 1995;131:73-7.

\section{Demand for donated eggs by ethnic minority groups exceeds the supply}

EDITOR,-Egg donation is an established fertility treatment for a variety of indications. The main limiting factor is the supply of donors, although the shortage may be confined to southern England. ${ }^{1}$ In the 1991 census ethnic minority groups comprised $5.5 \%$ of the British population, but egg donors who are not white are rare. We determined what in vitro fertilisation clinics in the United Kingdom were offering recipient couples from ethnic minority groups and whether women from these groups were donating their eggs.

The 46 licensed egg donation clinics in the United Kingdom were telephoned and asked what they would offer couples requesting egg donation who were not white and had not got their own donor, how many recipient couples from ethnic minority groups they had seen over the past two years, and how many anonymous egg donors had been recruited from ethnic minority groups during this time.

Twelve of the 46 clinics would offer a recipient couple from an ethnic minority group eggs from a white donor after counselling, and a further five would arrange eggs from a white donor for an Asian couple but not for a black couple. Three units would offer free in vitro fertilisation to women who were not white in exchange for half of their eggs. Only 17 women from ethnic minority groups had volunteered to become anonymous egg donors in the past two years, whereas 274 such couples had requested egg donation.

This survey shows that the demand for eggs from donors who are not white exceeds the supply available. Clinics are looking for alternative solutions. The use of eggs from white donors for recipients who are not white is offered by over a third of the clinics. This situation may be a second best option as it is unclear whether children born as a result of such donation would be fully accepted into their communities.

Offering free in vitro fertilisation to couples from racial minority groups in exchange for some of their eggs may be an acceptable option. Concerns have been raised, however, about how the donor couple would feel should their own treatment be unsuccessful.

The solution is to increase recruitment of donors from the recipient couple's community. Recipients usually wish to maintain confidentiality and cite this as their reason for not bringing their own donor. Recruitment could be improved through posters in an appropriate language; a clinic could act as an intermediary by contacting a sympathetic community leader, and it could also increase the general awareness of the public through the media.

In the future, techniques such as oocyte freezing and in vitro maturation of oocytes may obviate the need for egg donors. For now, however, egg donation clinics need to develop strategies to increase the awareness of the need for egg donors among all racial groups.

M A BIRDSALI Honorary senior registrar J M EDWARDS

Oxford IVF Unit,

Oxford Radcliffe Hospital,

Oxford OX3 9DU

1 Biljan MM, Taylor CT, Gosden CM, Jones SV, Malone CG, Kingsland CR. How acute is the acute shortage of oocyte donors in the UK? Results of a British national survey. $\mathrm{Br} F$ Obstet Gynaecol 1995;102:746-7.

\section{Laparoscopy does have a role in tuberculous peritonitis}

EdTor,-We question a statement made in the discussion of the Grand Round on tuberculous peritonitis. ${ }^{1}$ H J F Hodgson states that, "other things being equal, a trial of antituberculous treatment [rather than laparoscopy] is justified"; this comment is based on anecdotal experience of one patient who died when laparoscopy led to a laparotomy. The stated reason for Hodgson's concern is that "If one has multiple matted pieces of bowel, the process of performing a peritoneal biopsy at laparoscopy is itself hazardous."

In a report by one of us (JH) 22 patients who had tuberculous peritonitis underwent laparoscopy and peritoneal biopsy; there were no deaths and few complications. ${ }^{2}$ In a review Marshall commented on four reports on a total of 110 patients who underwent laparoscopy for peritoneal tuberculosis, with no deaths. ${ }^{3}$ The procedure is not, however, without risk, and occasional deaths have been reported, ${ }^{45}$ although these seem usually to have been associated with complicating factors. 